\title{
Tax Evasion, Tax Avoidance and Tax Planning in Australia: The participation in mass-marketed tax avoidance schemes in the Pilbara region of Western Australia in the 1990s
}

\author{
Alexander Robert (Lex) Fullarton \\ PhD Student Atax University of New South Wales \\ M Com (Taxation) (Curtin), \\ Dip Acct (TAFE), Dip Real Est. Mgt (TAFE) \\ ATTA FPNA FTIA AREI AIMM CD
}

$19^{\text {th }}$ November 2008

(C) A R Fullarton November 2008 


\section{Table of Contents}

$\begin{array}{ll}\text { Abstract } & 2\end{array}$

1 Introduction 3

2 Tax evasion, tax avoidance and tax planning 3

3 The recent history of tax avoidance schemes in Australia 6

3.1 The 'Bottom of the Harbour' schemes of the 1970s 10

3.2 Personal exertion and ‘income splitting’ 15

- family trusts and partnerships of the 1980s

3.3 Mass-marketed tax avoidance schemes of the 21 1990s

4 Conclusion 34

$\begin{array}{ll}\text { Bibliography } & 35\end{array}$

Figures

Figure 1: $\quad$ The cyclical pattern of tax avoidance scheme 8 development in Australia

Figure 2: $\quad$ The growth of mass-marketed tax avoidance 26 scheme deductions in the 1990s

Tables

Table 1: $\quad$ The impact of the ATO's test litigation program 30 on the number of mass-marketed tax avoidance schemes participants 


\begin{abstract}
$\underline{\text { Abstract }}$
This paper will examine the development of mass-marketed tax avoidance schemes in Australia. It will consider changes in approach to tax avoidance from the 'bottom of the harbour' schemes of the 1960s and 1970s to the mass-marketed tax avoidance schemes of the 1990s. It will examine the changing structure of tax avoidance from individually crafted tax avoidance structures designed by accountants and lawyers used by high wealth individuals to mass produced structures targeted at highly paid, and therefore highly taxed, blue collar workers in Australia's mining industry in the 1990s.
\end{abstract}

In the latter half of the twentieth century 'unacceptable' tax planning went from highly expensive, individually 'tailor made' structures afforded and used only by the very wealthy, to inexpensive replicated structures marketed to skilled and unskilled tradespeople and labourers. By 1998 over 42000 Australian taxpayers were engaged in tax avoidance schemes with the highest proportion focussed in the mining regions of Western Australia. In the remote and inhospitable mining community of Pannawonica, which has one of the highest paid workforces in Australia, the Australian Taxation Office identified that as many as one in five taxpayers were engaged in a mass-marketed tax avoidance scheme.

The paper will identify the causes of these changes, including the advent of the computerised information technology which permitted 'mass production' of business structures designed to exploit business incentives in the Australian taxation system in the 1990s. It will also set these developments within the broader context of the tax compliance culture prevailing in Australia and overseas during this period. 
" "The horror of that moment" the King went on, "I shall never, never forget!" "You will, though." The Queen said, "If you don't make a memorandum of it.",

(Lewis Carroll (Charles Lutwidge Dodgson), British Author, Anglican Clergyman and Photographer 1832 - 1898)

\section{Introduction}

The overall aim of this paper is to provide background and context relating to tax avoidance activity in Australia in the period from the beginnings of the 1970s through to the end of the 1990s.

This paper has three specific objectives. Firstly it provides working definitions of the concepts of tax evasion, tax avoidance and tax planning. The distinction between them is not critical to this analysis but it places them within the broader framework of tax reducing activities.

Secondly it examines the history of tax avoidance schemes in Australia from the early 1970s to the late 1990s. The paper analyses how tax avoidance schemes developed in Australia from the 1970s (focussed on High Wealth Individuals ('HWIs'), through the interposed entity structures used by high income blue collar workers in the 1980s, to the mass-marketed tax avoidance schemes of the 1990s. The mass-marketed tax avoidance schemes of the 1990s gained wide appeal to the blue collar workers of Western Australia's mining industry in the Pilbara region. This examination traces the changes in attitudes to tax compliance by that class of taxpayer, the Pilbara blue collar workers, which is the subject of this research.

Thirdly it looks broadly at taxpayers' responses to the Australian Taxation Office's (ATO's) subsequent review of deductions claimed through the use of tax avoidance schemes and recovery action of refunds issued by way of the ATO's self-assessment program. This examination is undertaken to establish the impact of taxation administration responses to the tax reducing activities of tax avoidance schemes participants on taxpayer attitudes to tax compliance

\section{Tax evasion, tax avoidance and tax planning}

Taxpayers often demonstrate a willingness to engage in tax reducing activities of one form or another. The methods used by taxpayers to reduce their tax liability may involve tax evasion, tax avoidance or tax planning and are determined by the morality, economic viability and/or legality of the particular method in a particular society or taxing jurisdiction.

It is acknowledged that compliance with taxation laws forms part of a subset of compliance with the law generally. Tyler suggests that People obey the law if they believe it's legitimate, not because they fear punishment. He finds that people obey law primarily because they believe in respecting legitimate authority. ${ }^{1}$

1 Tom R Tyler Why People Obey the Law (2006). 
The focus of this research concerns the influences which motivate taxpayers to engage in behaviour to reduce their tax. The common factor for all taxpayers in using tax evasion, tax avoidance and/or tax planning is the desire to pay less tax than they are otherwise burdened with. Therefore the distinction between tax evasion, tax avoidance and tax planning is not critical to this analysis.

The tax reducing activities do not have clear or distinct boundaries and generally shade from one to the other. Commentators such as Seldon ${ }^{2}$ see no economic distinction between tax avoidance and tax evasion. Seldon refers to the practice of reducing tax burdens by any means as 'avoison' being an amalgam of the two terms.

Despite not being critical to the objectives of this paper the three concepts of tax evasion, tax avoidance and tax planning do nevertheless, require a working definition to place them within the broader context of mass-marketed tax avoidance schemes development.

Tax evasion is the practice of reducing taxation liability by concealing income or declaring expenses or tax offsets that do not exist. ${ }^{3}$ Individuals and organisations which engage in activities outside of the law, in pursuits such as drug trafficking, are also unlikely to comply with taxation laws of a particular jurisdiction. Despite the unlikelihood of tax compliance it has been held '[assessable] income has been accepted as including the proceeds of criminal activities ${ }^{4}$ therefore those individuals and organisations are not only in breach of the law generally, but are also tax evaders.

Tax evasion may arise from an inadvertent error, omission or unintentional mistake, however if it is fraudulent, it is regarded as a crime. Freedman examines the situation where tax avoidance shades into fraud. ${ }^{5}$ She cites '. . . high profile cases in [the United Kingdom] where individuals, including tax professionals, have been successfully prosecuted for what they claimed were unsuccessful avoidance rather than evasion schemes. ${ }^{6}$ Freedman observes that ' $[\mathrm{t}]$ he test for dishonesty depends on a combination of findings of fact about what the defendant knew and believed and an application of the current standards of ordinary decent people. ${ }^{7}$ She also points out

\footnotetext{
2 Arthur Seldon, 'Avoison: The Moral Blurring of a Legal Distinction without an Economic Difference’ in Arthur Seldon(ed), Tax Avoison (1979) 1, 4.

3 Valerie Braithwaite, 'Dancing with Tax Authorities: Motivational Postures and Non-compliant Actions in Valerie Braithwaite (ed), Taxing Democracy: Understanding Tax Avoidance and Evasion (2003) 17, 32.

4 Commissioner of Taxation v La Rosa [2003] FCAFC 125, para 5.

5 Judith Freedman, 'Defining Taxpayer Responsibility: In support of a General Anti-Avoidance Principle’ (2004) 4 British Tax Review 332, 348.

6 See for example the much criticised $R v$ Charlton [1996] STC 1418, as cited in Freedman, above $\mathrm{n}$ 5, 348 .

${ }^{7}$ Freedman, above n 5, 348.
} 
that '. . . engagement in an avoidance scheme can encourage taxpayers to be economical with the truth. ${ }^{, 8}$

Tax avoidance differs from tax evasion in that it attempts to comply with the letter of the law while at the same time trying to gain a taxation benefit not intended by the legislature. If business structures are used to disguise transactions which were not intended to benefit from the tax relieving provisions or business arrangements it is sometimes referred to as 'unacceptable' avoidance. A concise definition of unacceptable tax avoidance is provided by Lord Goff in Ensign Tankers (Leasing) Ltd $v$ Stokes

Unacceptable tax avoidance typically involves the creation of complex artificial structures by which, as though by the wave of a magic wand, the taxpayer conjures out of the air a loss, or a gain, or expenditure, or whatever it may be, which otherwise would never have existed. ${ }^{9}$

Taxation systems often contain provisions deliberately targeted at stimulating certain commercial activities within the economy. Legitimate business structures may receive favourable taxation treatment and are referred to as 'acceptable' avoidance, generally termed tax planning.

Tax planning is the practice of arranging ' . . . the affairs of a taxpayer so that, within the bounds of the law, the incidence of income tax may be minimised. ${ }^{10}$ The basic premise of tax planning is best described '. . . In the words of Lord Upjohn 'No commercial man in his senses is going to carry out transactions except on the footing of paying the smallest amount of tax [possible]. ${ }^{11}$

The research underpinning this analysis focuses on mass-marketed tax avoidance schemes, therefore a closer examination of the concept of 'complex artificial structures' is warranted to place the mass-marketed tax avoidance schemes of the 1990s into the broader context of this study.

The techniques of tax minimisation using such artificial transactions are termed 'schemes'. They vary from transactions that '. . . are inherently worthless and which need no [legislative] provision to strike them down, ${ }^{12}$ to deliberate commercial contrivances which exist for no reason other than to avoid tax, or for which the 'dominant purpose' ${ }^{\text {,13 }}$ is to avoid tax. ${ }^{14}$

\footnotetext{
8 Ibid 349.

9 [1992] 1 AC 655.

10 Robin Woellner, et al. 1997 Australian Taxation Law 7th ed. (1997) 1416.

11 IR Commrs v Brebner (1967) 43 TC 718.

12 See eg Jacques v Federal Commissioner of Taxation (1924) 34 CLR 328 at 358.

13 Income Tax Assessment Act 1936 (Cth) sub-s 177A (5).

14 Income Tax Assessment Act 1936 (Cth) Pt IVA.
} 
Tax avoidance schemes take many forms, however often they constitute the promotion of non-existent or valueless projects, legally structured to provide income tax deductions, or similar tax benefits, to the subscribers. The deductions allowed for tax purposes are often greatly in excess of the sums outlaid by the taxpayers, hence the attraction to the tax avoider.

The relevance of the distinctions between unacceptable tax avoidance and tax planning to this research is that mass-marketed tax avoidance scheme designers, promoters and taxpayers rely on 'blurring' the distinctions to enable their unacceptable tax avoidance scheme to appear to be legitimate tax planning.

The paper now examines tax avoidance schemes which operated in Australia during the 1970s, 1980s and 1990s. This is to illustrate how schemes evolved from individually tailored schemes, used by HWIs in the 1970s, to broaden in scope to the mass-marketed tax avoidance schemes used by high income earning blue collar workers in the 1990s. The schemes did not supersede each other but rather developed from previous schemes which often remain in use by tax planners and taxpayers.

\section{The recent history of tax avoidance schemes in Australia}

A brief background to the development of the mass-marketed tax avoidance scheme reveals that it is a relatively modern economic concept. Tutt ${ }^{15}$ attributes the first designer of 'off-the-peg' mass-marketed tax avoidance scheme to Bernard Kimble, an English accountant, in 1965.

According to Tutt, the 'off-the peg' tax avoidance schemes began with a 'boutique'16 scheme designed to turn taxable income into non-taxable capital gains. These involved a complex dividend stripping ${ }^{17}$ array of trusts and companies that were designed for Miss Julie Christie, an English actress. ${ }^{18}$ Such structures had been used by his firm for film stars, composers and actors in England during the 1950s.

Clyne $^{19}$ also refers to 'off-the-peg' schemes but in 1969 he warned that '[tax avoidance schemes] must be tailored to measure, individualised, applicable to only one client . . . thus it will not present a broad front for the fiscal fiend ${ }^{20}$ to attack and

\footnotetext{
15 Nigel Tutt, The Tax Raiders: The Rossminister Affair (1985).

16 Designed for or directed to a small, specialised, fashionable market. (Macquarie concise dictionary $\left.4^{\text {th }} \mathrm{ed}\right)$.

17 The practice of purchasing shares in a private company with the intention of declaring dividends from the company's accumulated profits to the new shareholder, and then selling the shares in the company once the dividend has been paid (John Bernard et al (eds), Macquarie Concise Dictionary, (4th ed, 2006) 348).

18 Tutt states 'The scheme was consummated at a meeting at the Grosvenor House Hotel in Park Lane, London on December 22 1965’; Tutt, above n 15, 7.

19 Peter Clyne, The New Techniques of Tax Avoidance (1979).

20 Clyne's term for the Commissioner of Taxation.
} 
cannot be shot down as easily as the Curran scheme. ${ }^{21}$ In Australia 'off-the-peg' tax avoidance schemes included the Curran schemes, which used a form of dividend stripping, of the 1960s. These flourished into the 1970s for a number of reasons.

Myers suggests that the growth of Australian tax avoidance activity in the 1960s was due in part to the sympathetic view towards the taxpayer of the Barwick High Court. ${ }^{22}$ He cites Sir Garfield Barwick's statement as evidence of the reason for the 'boom' in the tax avoidance industry in Australia in the 1970s. Indeed Sir Garfield's findings in Curran v Federal Commissioner of Taxation ${ }^{23}$ tend to support the view that he focussed on the form of the transactions rather than the substance or intent behind them, applying a literal rather than purposive statutory interpretation.

Myers uses an excerpt from Sir Garfield's memoirs as evidence of judicial attitudes of the 1960s and 1970s, in which he (Sir Garfield) stated;

The liability to pay income tax is wholly derived from the law imposing and providing for the assessment of that tax. The obligation to pay it is a legal one. Some politicians try to treat it as a moral obligation. But it is not. The citizen is bound to pay no more tax than the statute requires him to pay according to the relevant state of his affairs. ${ }^{24}$

Evidence of taxpayer attitudes of the era to tax avoidance is indicated in Clyne's 1969 comments that:

Paying taxes is rather like alcohol, tobacco, heroin or wild women. It is simply a habit ... costly, addictive, soul-destroying and unnecessary. But in one way it does differ from alcohol, tobacco, heroin and wild women: - It offers no compensating element of pleasure, satisfaction or tranquillity. So one ought to kick the habit of paying taxes and develop the anti-habit of tax avoidance. ${ }^{25}$

Despite these personal attitudes of some of the judiciary and some taxpayers, when Australia joined the Organisation for Economic Co-operation and Development ('OECD') ${ }^{26}$ in 1971, its government was obliged to adopt the recommendation of the council on tax evasion and avoidance wherein the Council required the Governments of member countries:

(a) To strengthen, where necessary, their legal, regulatory or administrative provisions and their powers of investigation for the detection and prevention of tax avoidance and evasion, with regard to both their domestic and international aspects, and to exchange experiences with respect to such action;

21 Clyne, above n 19, 38; This book was written in 1979 but the warning referred back to his earlier book of 1969.

22 Allan J, Myers, ‘Tax Avoidance and the High Court since Sir Garfield Barwick’ (Lecture delivered at the Melbourne Law School, University of Melbourne, 12 April 2005.

23 (1974) 74 ATC 4296

24 Myers, above n 22, 3.

25 Clyne, above n 19, 9.

26 Organisation for Economic Co-operation and Development, 'International Tax Avoidance and Evasion’ Issues in International Taxation $(1987,1) 15$. 
(b) To facilitate, improve and extend exchanges of information between their national tax administrations, with a view to combating tax avoidance and evasion, notably by making more intensive use of international conventions or instruments in force and by seeking new arrangements of a bilateral or multilateral character, with due regard to the provision of adequate safeguards for taxpayers;

(c) To exchange experiences on a continuing basis on tax avoidance and evasion practices, on techniques for detecting and preventing them and on ways and means of improving tax compliance in general. ${ }^{27}$

The paper now examines tax avoidance activity in Australia from that point forward.

It appears that the development of tax avoidance schemes is a cyclical sequence of actions and reactions between taxpayers, scheme designers and promoters and tax administrators, the judiciary and legislators.

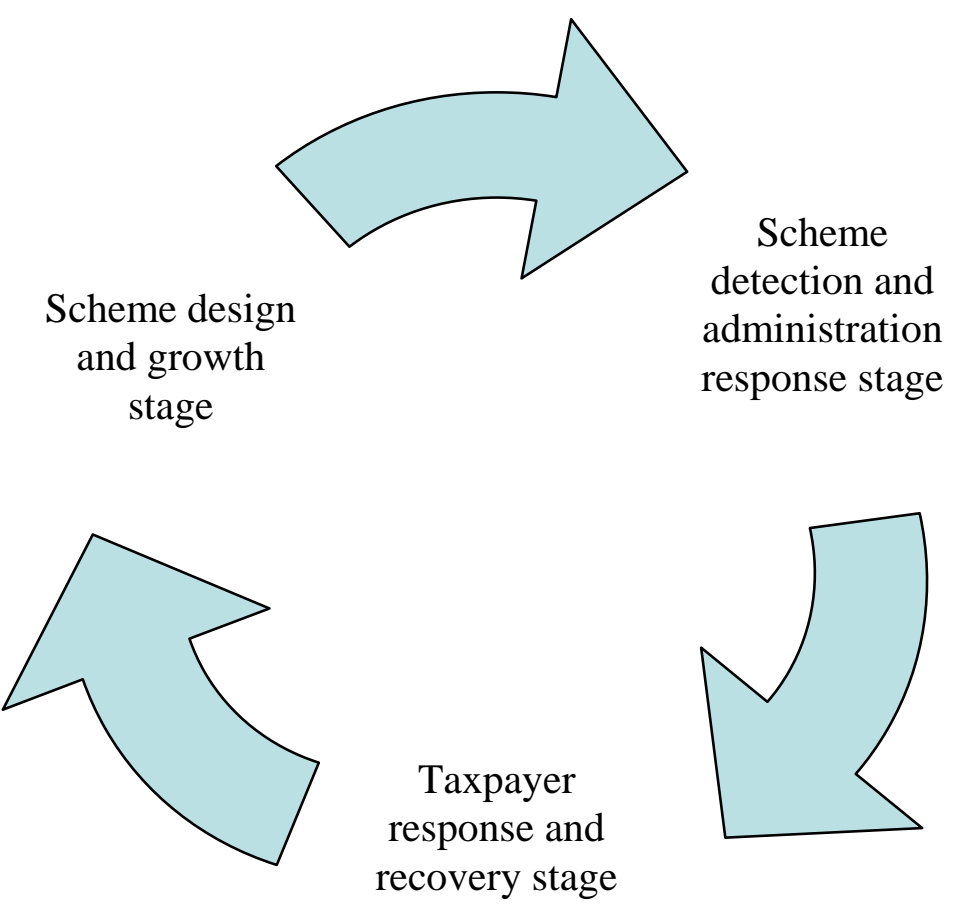

\section{Figure 1: The cyclical pattern of tax avoidance scheme development in Australia}

Scheme design and growth stage is the period of scheme development wherein accountants and other tax professionals react to taxpayer demand to find structures and methods of reducing their taxation burden.

It often involves investigation of legislation and anti-avoidance rules developed during the previous cycle as tax administrators, the judiciary and legislators respond to schemes developed in the cycle before that. An effect of actions and reactions by designers, taxation administrators and legislators and taxpayers within a series of cycles is that of tax avoidance schemes increases their complexity.

27 Ibid, 2. 
Successful tax avoidance schemes are developed and are taken up by taxpayers until they reach a volume, either by way of value or participants, which draws the attention of tax administrators.

Scheme detection and administration response stage is considered to begin when tax revenue losses and/or taxpayer involvement reaches a detectable point and becomes statistically significant. Tax administrators, in Australia the ATO; often note a fall in revenue which cannot be explained by other economic factors such as high unemployment. In the 1990s it was a significant volume and value of taxpayer refunds.

For the purposes of this thesis the role of tax administrators, the judiciary and legislators are considered as one group, that of 'tax administration'. Tax administrators take action to recover the losses which escalates to litigation. Judicial responses are included in this stage as success of prevention of further losses and/or recovery of tax revenue are critical to the administrators ability to respond. Weaknesses in legislation and action to prevent further similar schemes are enacted by law makers who change or make further laws to support the tax administrator's position. This stage may not necessarily consist of stricter enforcement measures but could result in other actions such as amnesties ${ }^{28}$ or lowering of tax rates ${ }^{29}$ to improve compliance.

Taxpayer response and recovery stage occurs as taxpayers are prevented from using the schemes and reconsider their attitudes to the payment of taxes. It also involves fiscal reconstruction to cope with tax compliance resulting from debts caused from the previous stage or future restriction of after-tax income. A pause in overt tax avoidance activity marks this stage as compliance is, or appears to be raised.

It appears that those cycles generally occur over a 10 year period. It is noted that each cycle produces a new scheme a little more complex than the previous one. The cycles should be viewed not as a flat plane of repetitiveness but rather three dimensional, as the cycle moves through time. It is also noted that the boundaries of the cycle are not clear and distinct points in time but rather move through a range from one stage to another.

Those cycles have generally occurred in each decade of the 1970s, 1980s and 1990s. This is a coincidental pattern and cycles are not rigidly a 10 year pattern. In the 1980s two cycles of scheme development, promotion, detection and response occurred. It is

28 Amnesties can have a negative as well as positive impact on tax compliance; Benno Torgler and Christopher A Schaltegger, 'Tax amnesties and political participation' in Benno Torgler (ed) Tax Compliance and Tax Morale: A Theoretical and Empirical Analysis (2007) 264.

29 There are considerably more factors affecting tax compliance however a relationship between compliance and tax rates has been identified by a number of researchers; Joel Slemrod and Shlomo Yitzhaki, 'Tax Avoidance, Evasion, and Administration' in Alan J Auerbach and Martin Feldstein (eds), Handbook of Public Economics (2002) 3, 1423, 1441; Benno Torgler, Tax Compliance and Tax Morale: A Theoretical and Empirical Analysis (2007) 22; John Brathwaite, 'Through the Eyes of the Advisers: A Fresh Look at High Wealth Individuals' in Valerie Braithwaite (ed), Taxing Democracy: Understanding Tax Avoidance and Evasion (2003) 245, 260. 
also arguable that the use of interposed entities began many years earlier than the 1980s and that they merely crystallised as tax avoidance schemes in the early 1980s.

It is convenient, for illustrative purposes, to treat the examination in decadal periods. This examination will therefore look at the tax avoidance schemes of each decade sequentially.

\subsection{The 'Bottom of the Harbour' schemes of the 1970s}

\section{Scheme design and growth stage}

Potas suggests that 'tax avoidance schemes were not widespread in Australia until the late 1960s and early 1970s. He considers that after 1970 tax avoidance activity was fuelled by a very restrictive interpretation of tax legislation adopted by the Australian courts. Judicial attitudes were such that virtually any tax avoidance scheme '. . . appears to have been outside the reach of the Commissioner of Taxation. ${ }^{30} \mathrm{He}$ continues that "during the 1970s the avoidance industry mushroomed. "Taxation planning" was actively promoted by professional lawyers and accountants. By the early 1980s, the amount of tax revenue being lost was variously estimated to be anything from $\$ 3,000 \mathrm{~m}$ to over $\$ 10,000 \mathrm{~m}$. 31

Grabosky states 'the schemes were simple, effective and fraudulent.' ${ }^{32}$ Braithwaite $^{33}$ also refers to the 1970s 'boom' in tax avoidance schemes and cites trading stock schemes as an example of those that '. . . succeeded before the High Court of Sir Garfield Barwick. ${ }^{34}$ He states that '[t]he most notorious schemes were crude asset strips called "bottom of the harbour" schemes." 35

The 'Bottom of the Harbour' schemes were identified as such in the Costigan Report. $^{36}$ The term came from the ultimate destiny of corporate documentation - to be thrown into the bottom of the (Melbourne) harbour to prevent scrutiny of administrative authorities and corporate regulators.

The 'Bottom of the Harbour' schemes involved stripping a corporate structure of its assets by way of dividends, disposing of the corporate shell by way of bankruptcy or selling it to an individual with no interest in corporate law. That person failed to

\footnotetext{
30 Ivan Potas, 'Thinking about Tax Avoidance' (1993) 43 Australian Institute of Criminology: trends $\&$ issues in crime and criminal justice, 2.

31 Peter Browne, 'Fair Shares, (1985) 52 Legal Services Bulletin as quoted in Ibid, 3.

32 Peter N Grabosky, 'The Deputy Crown Solicitor and the bottom of the harbour scheme' in Peter N Grabosky (ed), Wayward governance: illegality and its control in the public sector (1989) 143.

33 John Braithwaite, Markets in Vice; Markets in Virtue (2005) 37.

34 Ibid.

35 Ibid.

36 Commonwealth of Australia and Victoria, Royal Commission on the Activities of the Federated Ship Painters and Dockers Union, Interim Report 4 (1982) Vol 1.
} 
comply with corporate reporting requirements and the company was subsequently deregistered. The trading enterprise would continue under another corporate structure expressly incorporated for that purpose.

The Federated Ship Painters and Dockers Union ('FSDU') in Victoria was more than capable of providing '. . . dummy directors in the companies involved in those schemes. ${ }^{37}$ What was more than likely a mere 'sideline' for the FSDU became the thread by which the Western Australian 'Bottom of the Harbour' schemes were discovered.

According to Grabosky, the 'Bottom of the Harbour' schemes flourished in Western Australia and 'employed by hundreds of the more affluent members of the community to avoid paying taxes. ${ }^{38}$ Grabosky states '[t]he proliferation of extremely artificial tax avoidance schemes in the 1970s was to a large extent encouraged by members of the legal and accounting professions." ${ }^{39}$ And that ' $[t]$ he medium in which these massive frauds on revenue flourished was "bureaucratic inertia"., 40

When the 'bottom of the harbour' schemes were in full flower, the sums involved were millions of dollars, not hundreds of thousands. Indeed, the full cost of this chapter of Australian criminal history ran to thousands of millions of dollars. Some 7,000 companies were involved. ${ }^{41}$

The 'Bottom of the Harbour' schemes of the 1970s reflected community attitudes and perceptions towards the use of tax avoidance techniques, at least in terms of public visibility. A combination of rising tax rates, judicial permissiveness and apparent lack of action by the ATO lead to a surge in tax avoidance schemes so much so that it was suggested in 1978 in the Commonwealth House of Representatives that:

Tax dodging is taking a great deal of the talent of sections of the accountancy profession and is involving a large number of bureaucrats within the Government service in a continual game ... There is no doubt that never before in the history of Australia have we seen such concerted attacks on the revenue as have taken place in recent times. Never before have we seen such enormous volumes of revenue at risk as have been at risk in recent times. Those volumes are reaching ... extraordinary heights ... ${ }^{42}$

Waincymer notes that '. . . the 'Bottom of the Harbour' scandal of the 1970's [sic] was unique in its degree and impact and led a significant group in society to believe that paying tax was only for the foolish., ${ }^{43}$

\footnotetext{
37 Ibid.

38 Ibid.

39 Grabosky, above n 32, 144.

40 Ibid.

41 Grabosky, above n 32, 143.

42 Mr Baume, Member for Macarthur, 5 May 1978, as quoted in Woellner, above n 10, 1417.

43 Jeffrey Waincymer, 'The Australian Tax Avoidance Experience and Responses: A Critical Review' in Graeme S Cooper (ed) Tax Avoidance and the Rule of Law, (1997) 247, 248.
} 
An indication of the popularity of the 'Bottom of the Harbour' schemes is revealed by the following statement. 'The 1986-87 Annual Report of the ATO stated that these [1970s] schemes involved some 6688 companies and resulted in tax evasion of between $\$ 500 \mathrm{~m}$ and $\$ 1000 \mathrm{~m}$. 44 'The numbers are significant but a casual glance at the range of financial estimates implies that the true loss is incalculable. ATO statistics are merely those detected; many schemes would have been undetected. ${ }^{45}$

The paper now moves to how the schemes were detected and the response of taxation administrators.

\section{Scheme detection and administration response stage}

Scheme detection and administrative response was very slow. It appears that the schemes had existed for more than 10 years before they were detected. Further the schemes were detected almost by accident. In 1980 a Royal Commission was established to investigate the activities of the Federated Ship Painters and Dockers Union ('FSDU') in Victoria. ${ }^{46}$ The Royal Commission began as an investigation into the criminal activities of the FSDU in Victoria and exposed the existence of ' . . . a massive tax avoidance industry., 47

Grabosky's suggestion that the massive frauds on revenue flourished on 'bureaucratic inertia, ${ }^{48}$ was largely due to an administrative inability to deal with commercial and taxation legal complexity. His chapter on the Deputy Crown Solicitor's ('DCS') office involvement in the 'bottom of the harbour' schemes ${ }^{49}$ lays much of the 'bureaucratic inertia' at the hands of the DCS office in Perth Western Australia and specifically a Mr Abe Gleebman. ${ }^{50}$

In his defence Mr Gleebman asserts that despite being advised of the frauds in 1973 by the ATO, ${ }^{51}$ it was not '. . . until [the advice] was discovered in the course of inquiries by the Costigan Royal Commission in $1982 \ldots$. .52 that action took place.

\footnotetext{
44 Potas, above n 30, 3.

45 Michael D'Ascenzo, 'In Defence of the Rule of Law' (Speech delivered at the Taxation Law Workshop, Aitken Hill, Victoria, 26 - 28 October 2001) 11.

46 Commonwealth of Australia and Victoria, Royal Commission on the Activities of the Federated Ship Painters and Dockers Union, Final Report (1984) vol 1, 91. This report became known as the 'Costigan Report'.

47 Ibid.

48 Ibid.

49 Ibid 143 -158.

$50 \quad$ Ibid 145.

51 Ibid 144

52 Ibid 148.
} 
The Report of Enquiry Concerning the DCS Office, Perth ${ }^{53}$ concluded that there were a number of weaknesses in cases prosecuted by the DCS but they were generally of an administrative and clerical nature. The recommendations of the report ${ }^{54}$ focussed on improvements to information processing and record keeping. Liaison with 'client departments' was also recommended to be improved as well as interdepartmental contact.

Grabosky’s observed that:

The situation was expressed more bluntly by the outspoken Senator from Western Australia, Reg Withers ' $[w]$ hen I was a law student if you were a mug you went to work for the government. If you weren't much good you were referred to as 'real Crown Law material.'

Moreover, for those who were committed to a career in public service, salaries in the state crown law office were greater in the service of the Australian government. The most talented lawyers were thus not usually attracted to employment with DCS Perth. ${ }^{55}$

On the other hand, Mr Smith who carried out a detailed examination of the operations of the DCS Perth, found that:

The Office generally has a poor reputation - it is not able to attract quality staff. It is a small Office with few openings. ${ }^{56}$ He also states . . . the private profession has a poor opinion of the quality of the legal staff at the Perth Office. Similarly, the staff at the Office themselves are aware that they are held in low regard by the private profession. I expressed the view that this is unfortunate and said that I did not think the gap between to two was as great as has been supposed. I further expressed the view that some of the Officers are of high calibre and would make worthy contributions to any legal office. ${ }^{57}$

It is suggested that while some of the blame for the 'bureaucratic inertia' that lead to the time delay may rest on the DCS, the ATO must also accept some of that burden.

Support for the ATO's part in the 'bureaucratic inertia' factor may be found in evidence given later to the 2001 Senate inquiry, when Mr Michael D'Ascenzo, the then Second Commissioner said:

There is a reality about pursuing prosecution. I remember being involved in some of the bottom-of-the-harbour situations, where we had a Commonwealth task force involving a whole range of agencies. We did end up putting into jail a handful of promoters, but there were many that - [escaped] ... it just got too late in the piece. ${ }^{58}$

\footnotetext{
53 Commonwealth of Australia, Report of Enquiry Concerning the Deputy Crown Solicitors Office, Perth Anthony F Smith (1983) 134.

54 Ibid 136.

55 Grabosky, above n 32, 152.

${ }^{56}$ Commonwealth of Australia, above n 53, 81

57 Ibid 80.

58 Senate Economics References Committee, Parliament of the Commonwealth of Australia, Inquiry into Mass Marketed Tax Effective Schemes and Investor Protection Interim Report (2001) 21, (Senate Inquiry), second report 11.
} 
The delay in detecting and responding to the 'Bottom of the Harbour' schemes resulted in negligible direct taxpayer impact. Grabosky states there were only two prosecutions and that one of the convictions was later set aside. ${ }^{59}$

'Bureaucratic inertia' remains a problem for legal administrators and is not confined to tax administration. In a public statement in November 2008 WA Director of Public Prosecutions Robert Cock referred to a 10 year delay in prosecuting perpetrators of WA's 'finance brokers' scandal. '[T]he criminal justice system just didn't deliver. We got a few convictions, a few people spent a couple of years in jail. But really, we didn’t achieve what the system is supposed to achieve. ${ }^{60}$

It is not simply 'bureaucratic inertia' which 'emboldened' the promoters but according to Braithwaite ${ }^{61}$ other factors were also at work. ${ }^{62}$ He identifies four principal reasons for the (Bottom of the Harbour) tax avoidance scheme 'boom':

One was the Federal and High Court decisions unsympathetic to ATO enforcement that emboldened the promoters; another was payment of commissions to accountants and solicitors who referred vendors; a third was timidity and chain dragging by the ATO in taking action, and a fourth was "increased willingness of the community to participate in tax avoidance."63

In fairness to tax administrators, a factor which may have caused excessive delays in pursuing prosecution was a largely held belief that the anti-avoidance provisions of Section 260 of the ITAA1936 were ineffective. ${ }^{64}$ This view of Section 260 is reasonable given sympathetic view towards the taxpayer of the Barwick High Court. ${ }^{65}$ Braithwaite suggests the attitude of the courts in the 1970s had reduced the ATO to no more than a 'token enforcer'. ${ }^{66}$

There appears to be a link between Braithwaite's first and third principal reasons. If the Federal and High Courts demonstrate a bias, as Myers suggests, then it is reasonable for tax administrators to act timidly and 'drag the chain'.

The 'Bottom of the Harbour' schemes engaged in by HWIs of the 1970s were closed by legislation and the strengthening of Australia’s General Anti-avoidance Rules

\footnotetext{
${ }^{59}$ Grabosky, above n 32, 158.

${ }^{60}$ Paul Lampathakis, 'Justice Scandal:Brokers 'let off', The Sunday Times (Perth WA) 30 November 2008, 28.

${ }^{61}$ Braithwaite, above n 33.

62 Ibid.

63 Ibid; The fourth reason is that of Arie Freiberg, 'Ripples from the Bottom of the Harbour: Some Social Ramifications of Taxation Fraud’ (1998) 12 Criminal Law Journal 136, 137, as quoted in Braithwaite, above n 33, 37.

64 Waincymer, above n 43.

65 Allan J Myers, ‘Tax Avoidance and the High Court since Sir Garfield Barwick’ (Lecture delivered at the Melbourne Law School, University of Melbourne, 12 April 2005.

66 Braithwaite above n 33, 69.
} 
('GAARs') with the replacement of Section 260 by the introduction of Part IVA of the ITAA1936 in 1981. Section 15AA of the Acts Interpretation Act was also enacted in 1981 to require the courts to prefer a purposive approach to statutory interpretation rather than the literal approach which had frustrated many ATO prosecution cases. ${ }^{67}$

The introduction of Part IVA and Section 15AA addressed Braithwaite's first reason for the growth of tax avoidance schemes but the other three factors were not addressed by those amendments to legislation.

\section{Taxpayer response and recovery stage}

This stage occurred in the period between the late 1970s and the early 1980s. Taxpayer response is considered here as it relates to tax avoidance activity of the 1970s.

The criminality element of the 'Bottom of the Harbour' schemes highlighted by the Costigan inquiry, led many HWIs to distance themselves from involvement in schemes which where now more likely to be viewed as tax evasion or 'unacceptable' tax avoidance rather than tax planning. Taxpayers may have remained willing to reduce their tax burdens but were not so willing as to go to jail over it. Taxpayer response appears to be an acceptance of the 'new rules'.

The continuation of tax reducing activities into the 1980s indicates that the 'Bottom of the Harbour' schemes were not the end of tax avoidance scheme activity in Australia, but rather the beginning of the next cycle. The motivation to reduce tax remained, and tax avoidance scheme designers and promoters were to continue to develop and market tax reducing structures in the 1980s. However, as legislative measures to combat the 'Bottom of the Harbour' schemes were taken in the early 1980s, examination of this stage will be covered in the analysis of tax avoidance schemes in the following decade.

\subsection{Personal exertion and 'income splitting' - family trusts and partnerships of the $1980 \mathrm{~s}$}

This thesis asserts that tax reducing activity by HWIs did not cease with the closing of the 'Bottom of the Harbour' schemes. Tax avoidance activity by that class of taxpayer continues in modern times and the ATO now has a special task force established for investigating tax compliance by HWIs. ${ }^{68}$ It is also noted that in 1987 the famed British jockey, Lester Piggott, was jailed for tax evasion. ${ }^{69}$ Despite being a

\footnotetext{
67 In the interpretation of a provision of an Act, a construction that would promote the purpose or object underlying the Act (whether that purpose or object is expressly stated in the Act or not) shall be preferred to a construction that would not promote that purpose or object. (emphasis added) s15AA(1) Acts Interpretation Acts (1901) (Cth).

68 John Brathwaite, 'Through the Eyes of the Advisers: A Fresh Look at High Wealth Individuals' in Valerie Braithwaite (ed), Taxing Democracy: Understanding Tax Avoidance and Evasion (2003) 245, 247.

69 It is noted that failing to declare income (tax evasion), as in Piggott's case, not only evades income tax but in jurisdictions which have a Value Added Tax as was the UK in 1987, that tax component is also evaded.
} 
world famous figure and the holder of an Order of the British Empire ('OBE'), ${ }^{70}$ the lure of simply failing to declare income in order to save tax was overwhelming.

Another characteristic of the transition from the taxpayer response and recovery stage to the scheme design and growth stage is an apparent lack of tax avoidance activity.

Braithwaite states 'What is clear is that aggressive tax planning became much less aggressive during the 1980s and into the 1990s. ${ }^{71}$ Braithwaite endorses Levi's ${ }^{72}$ belief that voluntary compliance with Australian tax law improved during the 1980s as a result of the Hawke government's rebuilding of public confidence in the tax system, unprecedented public consultation and high profile prosecutions of 'Bottom of the Harbour' designers and participants, as plausible but unverifiable reasons for the apparent decline in tax avoidance activity. He quotes Devos, who notes a report that 'non-compliance detected in audits fell from a high of 87 percent in 1984-85 to a low 59 percent in 1990-91 after which it gradually began to increase again.' 73

Another possible explanation for the reduction in the detection of schemes in 1984 by the ATO as reported by Devos is that until the decision was made in Tupicoff, the ATO was not targeting income splitting arrangements. The ATO stepped back from strict application of Part IVA to what are considered 'family' partnerships. ${ }^{74}$

However Evans warns 'A cynic might suggest that this decision owes more to a pragmatic acceptance that there are simply too many such partnerships to challenge rather than the application of a principled approach to the issue. ${ }^{, 75}$

Taxpayers sought other methods of reducing their taxation burden and scheme designers were more than happy to oblige. Solicitors and accountants continued to refer clients to scheme designers. Taxation administrators remained outwardly tardy to react to tax avoidance activity and taxpayer demand to reduce taxation burdens had increased.

Tax avoidance activity in the 1980s expanded its taxpayer base. The development of the North West oil and gas fields off the Pilbara coast in the mid-1980s ${ }^{76}$ provided a

70 Most Excellent Order of the British Empire, ( $4^{\text {th }}$ level of the $5^{\text {th }}$ order of British Chivalry).

71 Braithwaite, above n 33, 38.

72 Margaret Levi, Of Rule and Revenue, (1988) as quoted in Braithwaite, above n 33, 38.

73 Ken Devos, Penalties and Sanctions for Australian Taxation Crimes and Their Effect on Taxpayer Compliance' (paper presented at the $5^{\text {th }}$ International Conference on Tax Administration, Atax UNSW, Sydney, 4 April 2002) as quoted in Braithwaite, above n 33, 38.

74 Taxation Ruling TR 94/8; Australian Taxation Office, 'Practical guide to Part IVA' (media release 2005/70, 13 December 2005).

75 Christopher Evans, 'The Battle Continues: Recent Australian Experience with Statutory Avoidance and Disclosure Rules' Judith Freedman (ed), Beyond Boundaries: Developing Approaches to Tax Avoidance and Tax Risk Management (2008) 37, 40. 
previously un-encountered source of tax avoider - the high income earning blue collar worker. ${ }^{77}$ The 1980s blue collar workers were not directly engaged in the Pilbara but rather were working on the construction of oil rigs and infrastructure that were fabricated in Kwinana, south of Perth in Western Australia. The rigs and gas plants were then transported by sea and road to the Pilbara upon completion in the late 1980s early 1990s.

During construction of the North Rankin 'A' oil platforms at Kwinana many of these workers were attracted to tax minimisation activities.

Two particular tax reducing methods were employed by scheme designers in the 1980s. Tax administration action to restrict the first method known as 'salary sacrifice' encouraged the development the second method by way of the use of 'interposed entities'. This thesis will look at these activities and the respective administrative responses separately.

\section{'Salary sacrifice'}

\section{Scheme design and growth stage}

Until 1986 blue collar workers were able to defray some of their taxed income with 'employee benefits'. Rather than receive taxable income employers paid employee expenses directly. Many private and domestic expenses such as travel to and from work, entertainment and domestic household expenses were paid for and on behalf of the employee.

The activity became known as 'salary sacrifice'. The employer was able to deduct the expense from assessable income as labour expenses. The employee did not receive the money but rather an undisclosed benefit. The employee avoided declaring the income and hence the tax. These arrangements were very simple 'employment agreements' which set out the terms and conditions of payments to be made on behalf of the employee.

The view 'that aggressive tax planning became much less aggressive during the 1980s and into the $1990 \mathrm{~s}^{, 78}$ may have overlooked the practice of salary sacrifice, which was 'acceptable tax avoidance' until 1986. The volume of tax avoided in this manner of tax planning would not have been accounted for and thus given rise to the beliefs of Levi, ${ }^{79}$ Braithwaite $^{80}$ and Devos ${ }^{81}$ that voluntary compliance with Australian tax law

\footnotetext{
76 North West Shelf LNG Pty Ltd, 'A Brief History of the North West Shelf', (Press Release, June 2003) < http://www.australialng.com.au/downloads/NWSALNG_brochure.pdf> at 15 February 2006.

77 Employment advertisements placed in The West Australian Saturday August 231997 show that trades people in the Pilbara mining industry were on the same remuneration as architects and other professionals at around $\$ 88000$ pa whilst those elsewhere in the same trades could expect to receive between $\$ 28$ - \$30 000 pa.

78 Braithwaite, above n 33, 38.

79 Levi, above n 72.

80 Braithwaite, above n 33, 38.
} 
improved. It may be that compliance did not improve but rather 'unacceptable tax avoidance' had crossed the boundary to 'acceptable tax planning'.

\section{Scheme detection and administration response stage}

'Salary sacrifice' did reach a detectable level and taxation administrators reacted to close the practice. As a measure to combat loss of taxation revenue through the use of 'salary sacrifice' employment agreements, Fringe Benefits Tax ('FBT') was introduced in 1986. This made the employer liable for the avoided tax which would have been paid by the employee had the income been paid directly to the employee.

The FBT has a further employer penalty in that it not only imposes the tax avoided by the employee, through direct expense payments, but also recovers the tax deductibility of the expense which would otherwise have been of a private and domestic nature. The payment is 'grossed-up' ${ }^{82}$ to increase the approximate value of the payment that the employee would have had to receive before tax to acquire the good or service purchased on the employee's behalf. A rate of 48.5cents in the dollar is then applied to the 'grossed-up' payment. ${ }^{83}$

A payment of $\$ 100$ grossed-up to $\$ 194.17$ and a tax rate of $48.5 \%$ or $\$ 94.17$ applied to it. The result was the employer was free to make payments on the employee's behalf but became liable for almost the same amount in tax. There are a number of exemptions, including payments to employees' superannuation to a limited extent, ${ }^{84}$ but in general the practice stopped.

\section{Taxpayer response and recovery stage}

The FBT affected the blue collar workers directly in that employers were limited in ways to pay tax exempt salaries. FBT resulted in employers becoming less enthusiastic to participate in the agreements and generally encouraged them to resort to direct employee payments.

\section{'Interposed entities'}

\section{Scheme design and growth stage}

The introduction of FBT stimulated the use of 'interposed entities' which is the construction of a legal entity between the employer and the employee. Initially

\footnotetext{
81 Devos, above n 73.

82 Prior to 2006-07 year the gross-up rate was $\frac{1}{1-\text { FBT rate }}=1.9417$

83 This was reduced to $46.5 \%$ as of $1^{\text {st }}$ April 2006.

${ }^{84}$ The case of Ryan v Federal Commissioner of Taxation [2004] ATC 2181 dealt with superannuation payments made by an employer husband to an employee wife. The case also considered interposed family entities and income splitting arrangements. The Commissioner of taxation sought to set aside the 'arrangement' under Part IVA however the matter was found in favour of the taxpayers. Detailed examination of the case is outside the scope of this paper but the exception is noted.
} 
employees argued that they were contractors being paid for services rather than for service. A good example of the practice of attempts made to circumvent the FBT is illustrated in the facts surrounding the case of Vabu Pty Ltd v Federal Commissioner of Taxation. $^{85}$

It did not take scheme designers and taxpayers long to realise that if they could interpose an entity to avoid FBT by changing an employee into a contractor, then maybe the entity could be made up of, at least nominally, a number of individual taxpayers and thereby take advantage of lower tax rates provided for under Australia's progressive tax rate system.

An example of the advantages of 'income-splitting' in the 1984 taxation year is demonstrated by the following case. An individual solicitor earns $\$ 40000,{ }^{86}$ the taxation assessed, ignoring rebates and other levies is \$ $14491 .^{87}$ By simply splitting that income with his wife, who cares for the home and children and has no other income, by way of a trust, the net tax on the same income is reduced to $\$ 9403$. In modern times the saving may appear trivial, but at the time $\$ 5000$ was a considerable sum of money. It is 12.5 per cent of gross income and a tax saving of over 35 per cent.

\section{Scheme detection and administration response stage}

Given the numbers of individuals involved and amounts of tax avoided, it is little wonder the use of interposed entities to distribute the income earned by individual personal exertion, became the target of tax administrators and legislators. ${ }^{88}$ Cases of welders, plumbers, electricians, architects, accountants and the like have drawn the ire of legislators whereby it is clear that other family members take no active part whatsoever in the enterprise and that the trust is simply a taxation minimisation scheme.

The earlier attempts at tax minimisation were made by taxpayers by way constructing trusts or other 'interposed entities' to permit income splitting between spouses and other family members and were addressed by the ATO in 1984. Taxation Ruling IT

85 (1996) ATC 4898.

${ }^{86}$ ATO statistics for 1984 are unavailable at this time however in Tupicoff v. Commissioner of Taxation, an insurance salesman, the sums involved were gross income of \$35 000 and \$10 492. The sums relate to activities in the 1978 year therefore the example of a solicitor earning $\$ 40000$ in 1984 is deemed reasonable for the purposes of this example.

87 Resident individual taxpayer rates 1983-84

\begin{tabular}{|l|l|}
\hline Taxable income & Tax on this income \\
\hline$\$ 1-\$ 4,594$ & Nil \\
\hline$\$ 4,595-\$ 19,499$ & 30 cents for each $\$ 1$ over $\$ 4,595$ \\
\hline$\$ 19,500-\$ 35,787$ & $\$ 4,471.50+46$ cents for each $\$ 1$ over $\$ 19,500$ \\
\hline$\$ 35,788$ and over & $\$ 11,963.98+60$ cents for each $\$ 1$ over $\$ 35,788$ \\
\hline
\end{tabular}

${ }^{88}$ ATO draft ruling 2005/d5.

< http://www.ato.gov.au/individuals/content.asp?doc=/content/73969.htm> at 15 June 2008. 
2121 set out official views in the light of a decision of the Federal Court of Australia handed down on 21 November 1984 in the case of Tupicoff $v$ Commissioner of Taxation. ${ }^{89}$

At first limitations placed on infant beneficiaries under Div 6AA of the ITAA 1936 as to the tax impositions on income over $\$ 416$ effectively prevent advantages of income distribution to minor family members for the purpose of tax minimisation.

These limitations were in response to a financial practice of changing the form or structure of an enterprise which enabled the proprietor(s) to distribute income to family members who were not otherwise involved in the business. The structures had no other purpose other than to reduce the incidence of tax. Often funds distributed to non-working family members were never placed in the control of the family member concerned. The funds remained in the control of the 'owners' and were 'paper' transfers only.

It is suggested that many children of these business proprietors were never aware of their 'income' and that income tax returns were lodged on their behalf by the 'trustee'.

In a number of decided cases a taxpayer who formerly carried on business, either alone or in partnership, ceased to do so, and instead became employed by the trustee of a family trust, who had acquired the relevant interest of the taxpayer formerly carried on by the taxpayer, and who then employed the taxpayer to provide services similar to those previously performed directly by the taxpayer. By these arrangements personal exertion income of the taxpayer was treated as income of the family trust, available for division by the trustee among members of the taxpayer's family.

However, in Tupicoff $v$ Federal Commissioner of Taxation (1984) 15 ATR 1262 the Full Federal Court applied s 260 of ITAA 1936 to annihilate such arrangements, leaving the net profit of the trustee company to be assessed to the taxpayer. In addition, in Federal Commissioner of Taxation v Gulland; Watson v Federal Commissioner of Taxation; Pincus $v$ Federal Commissioner of Taxation (1985) 17 ATR 1 the High Court applied s 260 to invalidate these arrangements for tax purposes. ${ }^{90}$

Subsequently interposed entities and alienation of personal services income have both been exposed as mere contrivances for tax avoidance. The established principle of substance over form has foreshadowed yet one more 'nail in the coffin' of the trust. The ATO further clarified its view on service trusts and income splitting arrangements in 1997 with a media release on 22 May $1997 .^{91}$

\section{Taxpayer response and recovery stage}

As with the Bottom of the Harbour schemes 'bureaucratic inertia' delayed the final determination of the interposed entity arrangements until the late 1990s. However in the early 1980s the ATO had determined the earnings of many of the blue collar

\footnotetext{
89 (1984) ATC 4851 and 15 ATR 1262.

90 Robert L Deutsch, et al, Australian Tax Handbook 2000 (2000) 755.

91 Australian Taxation Office, ‘Tax Office education on income splitting’ (Media Release, 22 May 1977).
} 
workers engaged in Western Australia's oil construction industry, as income from personal services and effectively stopped those schemes from proliferating. Generally tax professionals were aware that they could not arguably support the income splitting structures and the schemes lost favour in the late 1980s.

Examples of interposing trusts to split assessable income remain despite the ATO crackdown on 'personal services income' and the introduction of the New Business Tax System (Alienation of Personal Services Income) Act 2000. Many professionals and trades people establish trusts to enable income splitting with family members to reduce taxation burdens.

It is noted that should the taxpayer's attempt to form a partnership to carry out the same purpose it would fail for numerous reasons. There are licensing, regulatory or other legal or ethical requirements placed on the trade or profession. Rules of organisations such as the Legal Practitioners Board, the Medical Practitioners Board or other professional or regulatory bodies require partners to be qualified in the trade or profession in order for the partnership to be valid.

Numerous professionals such as medical practitioners, dentists, lawyers, accountants and the like continue to circumvent such controls which forbid splitting income with their spouses by way of partnership, by establishing 'service' trusts ${ }^{92}$ to achieve that end. The introduction of the alienation of personal services income provisions did restrict the use of interposed entities however rules can be circumvented. Such tax avoidance structures may be limited but they continue to be used.

As with the end of the 'Bottom of the Harbour' schemes and the tax avoidance activity of the 1970s the cycle of tax avoidance scheme was to move to another level. A significant outcome of the development of the tax avoidance structures of the 1980s was that the concept of tax minimisation structures had been introduced to the blue collar worker of Western Australia. Braithwaite's fourth factor ${ }^{93}$ had increased in its scope to encompass another class of taxpayer, and the focus of this research, the blue collar worker as well as the previously targeted HWIs.

The examination moves with the cycle of the development of tax avoidance schemes to the 1990s.

\subsection{Mass-marketed tax avoidance schemes of the 1990s}

With the legal alternatives of 'salary sacrifice' and interposed entities restricted it took tax professionals a while to reassess their situation and seek other vehicles to continue their tax minimisation activities. In Braithwaite's terms, market forces continued to demand tax reducing schemes.

The role of tax professionals in the 'Bottom of the Harbour' schemes was and remains an integral part of Australian tax law interpretation and administration. Braithwaite

\footnotetext{
92 The legal validity of 'service trusts' was the principle issue of the case of the 1978 Phillips $v$ Federal Commissioner of Taxation (1978) ATR 783.

93 “Increased willingness of the community to participate in tax avoidance.” Braithwaite, above n 33.
} 
suggests that the last three of his principal reasons were the major drivers of the massmarketed tax avoidance schemes of the 1990s.

The causal factors which influenced the development of the 1970s 'Bottom of the Harbour' schemes were identified by Waincymer and Braithwaite as being motivational factors driving the development of the mass-marketed tax avoidance schemes of the 1990s. This tends to indicate that tax administrators, the judiciary and legislators may have addressed the problem but not the cause.

\section{Scheme design and growth stage}

The mass-marketed tax avoidance schemes of the 1990s used a mixture of existing corporate structures, taxation law and ATO procedures to contrive complex and effective taxation avoidance schemes. The use of these structures supports the view that undue complexity leads to an increase in tax evasion/avoidance/tax planning activities rather than combating them. ${ }^{94}$

While there was a 'white collar crime' aspect to the mass-marketed tax avoidance schemes of the 1990s and the designers and promoters of the schemes were accountants, tax professionals and lawyers, the largest social group which participated in the mass-marketed tax avoidance schemes of the 1990s were blue collar workers. In particular in Australia in the 1990s, it was the blue collar workers of Western Australia's mining regions.

\section{Evans notes that}

The growth in the mid to late 1990s of mass-marketed tax avoidance schemes pedalled by the 'white shoe brigade, ${ }^{95}$ to high income blue collar workers operating in the resources sectors in the remoter parts of Australia has shown that tax avoidance activity is now a much more comprehensive and extensive phenomenon than was the case in earlier years. ${ }^{96}$

Another element in the success of tax avoidance schemes in Australia was the introduction of a 'self-assessment' program in 1987. The introduction of computerbased technology brought with it an unreasonable expectation that income tax returns and the resultant refunds to wages and salary income earners, would be commensurately faster. The ATO promoted the concept of the 14 day refund if lodged electronically.

\footnotetext{
94 Valerie Braithwaite, 'Tax System Integrity and Compliance: The Democratic Management of the Tax System' in Valerie Braithwaite (ed), Taxing Democracy :Understanding Tax Avoidance and Evasion (2003) 271, 277; Zoë Prebble and John Prebble, 'The morality of Tax Avoidance: Why the Legal Difference Between Evasion and Avoidance is Insufficient to Ground a Moral Distinction’(paper presented at the Australasian Tax Teachers Association Annual Conference University of Tasmania, January 2007) 7; Benno Torgler, Tax Compliance and Tax Morale: A Theoretical and Empirical Analysis (2007) 56; Waincymer, above n 43, 270; Paul Webley, 'Tax compliance by business' in Hans Sjögren and Göran Skogh (eds), NewPerspectives on Economic Crime (2004) 95,96;

95 A derisive term originally coined to describe the property developers who worked with Sir Joh Bjelke-Petersen, Premier of Queensland, in a number of suspicious deals in the 1960s, 1970s and 1980s in Queensland.

96 Evans, above n 75, 37.
} 
Given that the average processing time had been around three months, the 'selfassessment' program was viewed as a boon to the Government and taxpayers alike. Detailed examination of the returns however was sacrificed for increased processing rates. The ATO retained the right to re-assess income tax returns for a period of six years. It was under the 'reviewing' provisions that the re-assessments were carried out in 1999-2000 year and backdated to 1994.

The principle of allowing deductions to be processed unchallenged through the assessing system of the Australian Tax Office in order to facilitate timely refunds to taxpayers, created an avenue for tax avoidance schemes to proliferate.

However the introduction of self assessment in 1987 did not herald an immediate proliferation of tax avoidance schemes. It took a further seven years for taxation administrators to notice the real effect of self assessment, and the accompanying ATO time delay in dealing with tax deduction claims.

The more astute tax avoidance scheme compilers took the Australian taxpayers and legislators through an intricate contrivance of commercial structures and transactions. The electronic lodgement system and the 14 day 'no questions asked' self assessment process not only streamlined tax assessment, but delayed examination of deductions claimed for a minimum of two years, with some examinations delayed so long as to be prevented by the Statute of Limitations, six years.

It appeared to mass-marketed tax avoidance schemes promoters and participants that tax avoidance was able to 'cross the boundary' to appear as acceptable tax planning as it did with the 'salary sacrifice' provisions of the 1980s.

The mass-marketed tax avoidance schemes took many forms and ultimately over 196 were reviewed by the ATO in 2001. ${ }^{97}$ Examples of contrivances range from that of a marginal avoidance scheme which had a basis of substance, to an outright contrivance with little or no regard for substance whatsoever.

The following mass-marketed tax avoidance schemes from the 1990s are outlined to indicate how they functioned as a range of 'investments'.

The Banalasta Oil Plantation Limited scheme was an investment in a tree plantation, by way of non-recourse loan. It was held out that the plantation was to produce natural oils for medical and cosmetic purposes. The investors were induced to enter into an arrangement whereby deductions allowed under agricultural industry incentives where offset against other income. The operation fell into the second category, however non-recourse loans inflated taxation deductions and are classified into the first category.

A loan, payable only out of profits from the venture and not otherwise enforceable against the investor, was granted by the promoter to the investor for a fee. The

97 D’Ascenzo, above n 45, 1. 
investor then claimed the full sum of the 'investment' as a deduction in the year the arrangement was made.

The scheme purported to be well documented and contracts prepared by legal practitioners were executed in support of the arrangement. This scheme was identified by the ATO as a tax avoidance scheme and the deduction allowed was limited to the actual cash outlaid to the project. On average, around ten percent of the original deduction claimed was actually incurred by the taxpayer, and subsequently allowed by the ATO.

It appears that the dominant purpose of the scheme was therefore to avoid tax. However evidence of the activities of Plantation Equity Pty Ltd and the promotion of their products has been published on the internet ${ }^{98}$ indicate this may well have been a genuine investment.

Main Camp Tea Tree Project No. 4 was a genuine agricultural project. The tea tree plantation continues to produce forest product, however, in the examination of tax avoidance schemes held by the Commissioner of Taxation in 2000, it was found that many of those schemes, though sometimes genuine in the production of the end product, involved a series of non-recourse loans to shareholders, which artificially inflated an otherwise genuine and legitimate deductible expense. Its operation fell into the second category - an agricultural product which received favourable taxation treatment. The non-recourse loans were of the first category.

Not all investors contributed to the project by way of non-recourse loans, some contributed significantly in cash. During the recovery action by the ATO, investors who had paid the investment without resort to the loans were granted deduction for all monies actually contributed to the project. In some cases as much as \$14 200 were paid by 10 April 2002 of the original non-recourse debt of $\$ 23500$ taken out on 30 June 1995. $^{99}$ The balance of the loan, being \$ 9300, was never recovered by the company. However to date the administrator has not made a claim for the balance on the investor, nor have any loan statements been issued to the investor since 10 April 2002.

This scheme was the forerunner of the plantation industry based mass-marketed tax avoidance schemes. The tea tree plantations were established by '. . . Glendon Michael Stotter, the Chairman of Directors of B[usiness] a[nd] R[esearch] M[anagement Limited]. From March 1992 to October 1995, Mr Stotter was involved in the establishment of the Main Camp Tea Tree Oil Projects Nos 1-4, which had raised funds from the public pursuant to registered prospectuses, for the purpose of establishing tea tree plantations on property at Main Camp near Casino in northern New South Wales. The development of that property was described by Mr Stotter as successful., 100

\footnotetext{
$98<$ http://www.banalasta.com.au/homes.php?xid=83460b88f4521df5685a00883e7da34b> at 23 June 2008.

99 Documents provided by a scheme participant.

100 Howland-Rose and Ors v Federal Commissioner of Taxation [2002] FCA 246 at point 5.
} 
Satcom Electronic Commerce Services Pty Ltd was overtly a franchise system of business structure selling licences to access a search engine on the Internet. Its operation fell into the first category. This scheme was a mixture of a genuine attempt to produce and market a computer-based information technology system at a time of information technology (IT) euphoria and a blatant fraud. Investors were invited to pay a \$ 3000 administration fee in exchange for an invoice for franchise fees of \$ 64 000 .

Investors then claimed the \$ 64000 as business expenses and subject to their marginal income tax rate received a refund of up to $\$ 32000$. The first refund was transferred to the promoters as a repayment of a 'loan'. The refund was transferred to the promoter on the grounds that the tax saving would be indefinite. Shortly after 1999 the promoter disappeared from Western Australia and the company was wound up. Its only asset, an internet search engine, was sold to the Commonwealth Bank by the Liquidator.

In almost all cases the franchisees never attempted any business transactions to support their argument of genuine businesses. It is doubtful that a blue collar worker in the Pilbara working 12 hour shifts on a mine site in over $50^{\circ} \mathrm{C}$ conditions would be aware of the intricacies of franchising businesses let alone have the market or the resources to 'actively engage in business pursuits'.

Satcom Electronic Commerce Services Pty Ltd. was registered in February 1997, in Western Australia ${ }^{101}$ and all references are to Western Australian residents and places. The Western Australian operation partially satisfies the focus on Western Australian taxpayers.

The common thread of all of the schemes is that 'investors' were claiming tax deductions for monies they had not paid. The 'business debts' were financed by way of 'loans' from the promoters and were never legally valid.

The introduction of 'self-assessment' introduced a further factor to the development of mass-marketed tax avoidance schemes which appeared to give the appearance of legitimacy. Participants deducted the invalid 'business expenses' from their taxable income, through the use of the self-assessment program and the ATO to 'over refunded' taxpayers 'pay as you go' ('PAYG') contributions.

This additional factor was exploited not so much by the taxpayers who were ultimately liable to repay the over refunds, but by the promoters who in at least one case expropriated the 'tax refund' from the taxpayer to themselves. The key to the success of a good tax avoidance scheme, as demonstrated by the promoters of the Satcom scheme, is being aware of detection. An exit strategy is essential when detection is imminent and the 'self-assessment' system gave the Satcom promoters a two year lead time to dissolve the company and remove themselves from investigation by legal authorities and 'investors'.

101 Company registration details Satcom Electronic Commerce Services Pty Ltd. ACN 077650269. Extracted from Australian Securities \& Investments Commission database at 10:58:52 on 22 December 2005. 
The Ord River Sandalwood Company, known as Kununurra Sandalwood, operated large timber plantations in the Ord River irrigation district in the Kimberley region of Western Australia. Thousands of hectares of Indian sandalwood, teak and other exotic millable timbers were grown and managed by Lincfel Enterprises Pty Ltd on behalf of Allrange Tree Farms Pty Ltd. Investors were allocated 'timber lots' and purchased 400 Indian Sandalwood seedlings with East African ebony, rosewood, mahogany and Acacia host tree seedlings.

A contract of sale was executed and stamped for the purchase of the seedlings and the management and maintenance of the 'woodlot' between the investor, Allrange Trees Farms and Lincfel Enterprises. The sandalwood operation continues as of the date of writing which has made the interpretation by the ATO that it is a tax avoidance scheme difficult to understand to the investors.

The thesis now looks at the ATOs action to recover the 'over refunds' that had emanated from the schemes and taxpayer responses to that recovery action.

\section{Scheme detection and administration response stage}

As with the transition from 'Bottom of the Harbour' schemes of the 1970s to the interposed entities of the 1980s, tax avoidance activity appeared much less aggressive in the early 1990s. It was not until 1996 that authorities began to notice 'termites' in the fiscal structure. ${ }^{102}$

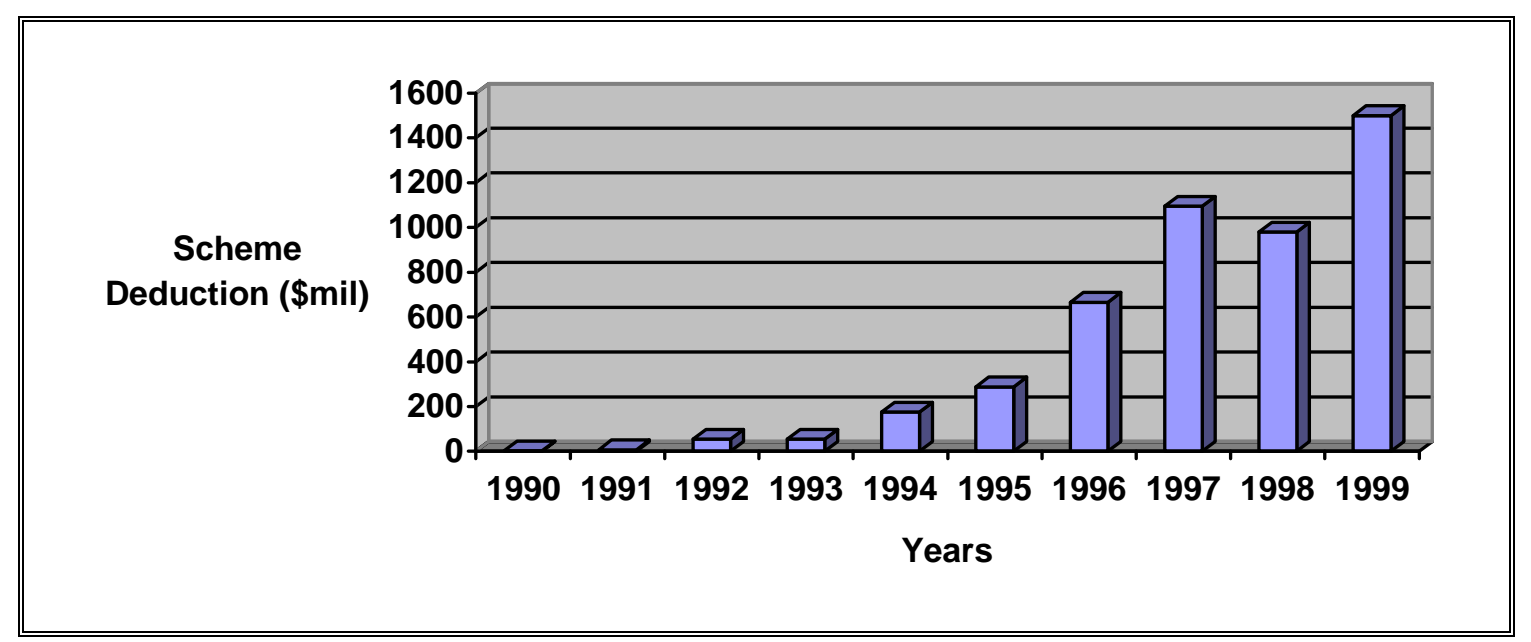

Figure 2: The growth of mass-marketed tax avoidance scheme deductions in the 1990s

$$
\text { (Sources: D’Ascenzo; }{ }^{103} ; \text { Murphy }{ }^{104} \text { ) }
$$

102 A term coined by Vito L Tanzi 'Globalization, Technological Developments, and the Work of Fiscal Termites’ (Working Paper No. 00/181International Monetary Fund, November 2000); and used by Braithwaite, above $n 33$.

103 D’Ascenzo, above n 45, 3. 
It is noted that Australian Securities and Investments Commission warnings as to 'shonky' tax scheme promoters were issued in April 1997. The ATO established its 'schemes task force' in July and issued its warning on 'tax effective' schemes in October of that year. ${ }^{105}$

The lack of overt ATO response was viewed by many as actual, if not tacit, approval of the schemes. In many cases the ATO was issuing product and private rulings indicating the Commissioners' approval of particular projects. In most cases, these rulings were later withdrawn.

In its examination the Senate Committee considered the role of the delay in ATO action of the growth of mass-marketed tax avoidance schemes in the 1990s. In its submission to the Senate committee, the ATO's defence was that the nature and scale of the mass-marketed tax avoidance schemes were such that it responded as quickly as it could.

From 1994 to 1998 the ATO was constrained due to the time taken to prepare and litigate cases, all the while scheme designers and promoters marketed to taxpayers who enthusiastically participated in the mass-marketed tax avoidance schemes.

The mass-marketed tax avoidance schemes of the 1990s were broadly categorised by the ATO into three groups:-

- A system of exchange of loan contracts (round robin financing and nonrecourse loans) whereby the funds for 'deductible' business expenses were 'loaned' to taxpayers to be repaid out of future profits from the respective 'business' venture;

- Certain film and other investments granted favourable taxation treatment by Australian tax legislation; and

- Employee - benefit arrangements (salary sacrifice)

The third category, which involved employee benefit arrangements, was significantly different to the mass-marketed tax avoidance schemes which are the focus of this thesis. Participants needed to be employers to set up the appropriate financial structures and the average tax debt was significantly higher than that of the average

\footnotetext{
104 Kristina Murphy, 'The Role of Trust in Nurturing Compliance: A Study of Tax Scheme Investors' (Paper presented at the Current Issues in Regulation: Enforcement Compliance Conference, Melbourne 2-3 September 2002) 3.

105 Australian Taxation Office, 'Tax Office on target' (media release 97/50, 30 ${ }^{\text {th }}$ October 1997); The media release makes reference to 'aggressive tax planning' but it is, at best, a veiled threat rather than notice that the ATO intends to address the matter. Merely making a statement that 'We are experiencing the increasing globalisation of business and a great deal of legislative activity to counter aggressive tax planning' does not imply action will be taken, particularly when it wasn't. Only an astute observer would have perceived the threat. The more emboldened promoter may have viewed it as tacit approval of the mass-marketed tax avoidance schemes.
} 
mass-marketed tax avoidance schemes participant. Analysis of this category is outside the scope of this thesis.

The ATO initiated a 'test litigation program' in 1995 on the basis that guiding principles of tax law interpretation could be established by legal precedent. In this program a point of law is 'tested' by litigation in the High Court of Australia. The principle of the test litigation program is that the Commissioner applies the decision based on the findings of the 'test case' to use Part IVA to deal with every participant of a particular mass-marketed tax avoidance schemes structure. ${ }^{106}$ Those findings became the basis on which the Commissioner of Taxation acted to disallow deductions previously claimed by all taxpayers involved in the designated schemes.

By categorising mass-marketed tax avoidance schemes the ATO could then deal with a number of similar structures and review thousands of individual taxpayers at a time. Seven cases have been chosen to demonstrate the effectiveness the 'test litigation program' or collective treatment of taxpayers which relate to the mass-marketed tax avoidance schemes of the 1990s. The statistics are illustrated in Table 1 and the cases broadly stated below.

Cooke \& Jamieson v Federal Commissioner of Taxation [2002] FCA 131575 dealt with the 'dominant purpose' of an investment scheme. It was held that the dominant purpose of the scheme was to generate income for the participants' retirement rather than enabling them to obtain a tax benefit.

Howland -Rose v Federal Commissioner of Taxation [2002] FCA 246 dealt with expenditure on research and development of a tea-tree plantation. Income relating to the expenditure was to be in excess of 13 months from the date of the expenditure. Therefore the expenditure was denied pursuant to s $82 \mathrm{KZM}{ }^{107}$ It was held that the expense was not relevant or incidental to the production of assessable income.

Vincent v Federal Commissioner of Taxation [2002] FCAFC 291 dealt with the validity of business expenses incurred by way of debts to financiers through the use of non-recourse loans. It was held that the dominant purpose of the transactions was to enable her and other taxpayers to obtain tax benefits in connection with the scheme. It was further held that Part IVA of the Act applied to the scheme and that deductions previously allowed (under the self-assessment program) were correctly disallowed.

Meredith v Federal Commissioner of Taxation [2002] FCAFC 271 dealt with the Commissioner of Taxation's powers to issue amended assessments. The plaintiff asserted that the amended assessments issued to the participants of the Satcom 'investment' were invalid. It was held that the Commissioner was authorised to issue amended assessments.

Krampel Newman Partners Pty Ltd v Federal Commissioner of Taxation [2003] FCA 123 dealt with investment in a 'film investment' pursuant to Div 10BA. ${ }^{108}$ The film

\footnotetext{
106 Tom Delany, 'Part IVA and mass marketed schemes’ (2005) 8(4) The Tax Specialist.

${ }^{107}$ ITAA 1936.

${ }^{108}$ Ibid.
} 
never completed final production. It was held that the investors had not acquired to copyright to the relevant film in the year of expenditure.

Puzey v Federal Commissioner of Taxation [2003] FCAFC 197 dealt with an investment in a sandalwood plantation. Unlike the findings in Vincent $v$ Federal Commissioner of Taxation [2002], it was held that the taxpayer was carrying on business and that, but for Part IVA, the expenses would have been deductible. Management fees of $\$ 800$ were allowed as a revenue expense.

Federal Commissioner of Taxation v Sleight [2004] FCAFC 94 dealt with the concept of carrying on business as a primary producer as a partner in a 'managed farm investment' and business expenses paid by way of a non-recourse loan disallowed. It was held that actual cash expended was deductible but that was of a capital nature and not deductable against ordinary income. 


\begin{tabular}{|c|c|c|c|c|}
\hline Scheme & Case & Year & $\begin{array}{l}\text { Number of taxpayer's } \\
\text { re-assessed }\end{array}$ & $\begin{array}{c}\% \text { of total } \\
\text { participants }\end{array}$ \\
\hline $\begin{array}{l}\text { Australian } \\
\text { Horticultural } \\
\text { Project no } 1 .\end{array}$ & Cooke & 2002 & & \\
\hline $\begin{array}{l}\text { Main Camp } \\
\text { Tea Tree } \\
\text { Project }\end{array}$ & Howland - Rose & 2002 & 2371 & 7.297 \\
\hline $\begin{array}{l}\text { Active Cattle } \\
\text { Management }\end{array}$ & Vincent & 2002 & Several hundred & \\
\hline Satcom & Meredith & 2002 & $>1121$ & \\
\hline $\begin{array}{l}\text { Film } \\
\text { Investment } \quad- \\
\text { Mephisto's } \\
\text { Web }^{111}\end{array}$ & $\begin{array}{l}\text { Krampel } \\
\text { Newman } \\
\text { Partners Pty Ltd }\end{array}$ & 2003 & & \\
\hline $\begin{array}{l}\text { Kununurra } \\
\text { Sandalwood }\end{array}$ & Puzey & 2004 & & \\
\hline $\begin{array}{l}\text { Northern } \\
\text { Rivers Tea } \\
\text { Tree }\end{array}$ & Sleight & 2004 & & \\
\hline
\end{tabular}

Table 1: The impact of the ATO's test litigation program on the number of mass-marketed tax avoidance schemes participants

(Source ATO ‘Schemes’ office)

Nonetheless, given the magnitude of tax avoidance schemes and taxpayers involved, the ATO continued to face the considerable task in identifying and addressing each taxpayer and scheme involved. In 1998 the ATO issued some 57000 amended assessments under Part IVA of the ITAA 1936 to recover taxes which had been avoided, in the Commissioner's opinion, through the use of contrived entities. One hundred and sixty five entities were deemed 'eligible schemes' and taxpayers had many millions of dollars of income tax deductions retrospectively disallowed.

The policy of 'testing' the Commissioner's advice further developed into a program by the ATO with the Commissioner issuing this notice on 21 April 2005.

The Australian Government and the community expect us to provide greater certainty about the laws we administer. Although we provide binding advice and extensive information about tax administration, ultimately the courts have the final say in determining what our laws mean.

Under the Test Case Litigation Program we provide financial assistance to taxpayers involved in litigation that we regard as being important to the administration of the revenue system.

\footnotetext{
109 Being provided by ATO schemes not yet to hand.

110 Based on the number of scheme participants of 32493 as identified by Kristina Murphy and Karen Byng, 'A User's Guide to 'The Australian Tax System Survey of Tax Scheme Investors' ' (Working Paper No 39, Centre for Tax System Integrity, 2002).
} 
The purpose of the program is to develop legal precedent, that is, legal decisions that provide guiding principles on how laws should be applied. This initiative has provided greater certainty to taxpayers since the start of the program in $1995 .{ }^{112}$

The policy has reached a level at which the Commissioner of Taxation has offered to 'provide financial assistance to taxpayers involved in litigation that we regard as being important to the administration of the revenue system. ${ }^{113}$

However timing of the 'test cases' and the amended assessments indicates that the ATO did not rely entirely on the findings of the cases but rather acted in response to earlier cases such as Spotless ${ }^{114}$ and Peabody ${ }^{115}$ in applying Part IVA to disallow the deductions claimed under the schemes. It is also noted that some of the projects actually existed such as the Main Camp Tea Tree and Kununurra Sandalwood tea tree plantations. In some cases such as the Kununurra Sandalwood it was not that the expenses had not occurred but rather the distinction of who was carrying on business and whether the expenditure was of a revenue or capital nature. ${ }^{116}$

It was not the physical existence of the projects that determined the Commissioner's decision but rather other factors such as the tax-effectiveness or 'dominant purpose'. In adopting that position the Commissioner focussed on the intent of the purpose of taxation legislation rather than the literal, or 'black letter law', interpretation.

\section{Taxpayer response and recovery stage}

Understandably there was considerable taxpayer angst and a great deal of government, professional and taxpayer resources have been directed at resisting and understanding the underlying motivation and consequences of the mass-marketed tax avoidance schemes as well as the consequences of the Commissioner's action in response to them. Taxpayers protested strongly against the amended assessments.

Documents obtained from scheme participants confirm that legal practitioners and accountants who were involved in the design, promotion and implementation of at least two schemes, Satcom and the Kununurra Sandalwood project, established 'fighting funds'. ${ }^{117}$ The fighting funds were conducted by companies incorporated for the purpose of financing the legal actions of David Meredith (Satcom) ${ }^{118}$ and Noel

\footnotetext{
112 Test Case Litigation Program.

$<$ http://www.ato.gov.au/taxprofessionals/content.asp?doc=/content/57395.htm> at 12 July 2008.

113 Ibid.

114 Federal Commissioner of Taxation v Spotless Services Ltd (1996) 34 ATR 183.

115 Federal Commissioner of Taxation v Peabody (1994) 28 ATR 344.

116 Puzey v Commissioner of Taxation [2004] HCA Trans 426 (28 October 2004).

117 Documents provided by private correspondence between scheme participants and Alexander R Fullarton.

118 Resolution Holdings Pty Ltd; Meredith v Commissioner of Taxation [2002].
} 
Puzey (Kununurra Sandalwood). ${ }^{119}$ Scheme participants were solicited to contribute to the fighting funds and in one case, Resolution Holdings Pty Ltd, participants continued to be asked to contribute to the fund for some time after the company had been wound up in December 1999. ${ }^{120}$

The general attitude in Western Australia to the ATO's re-assessment of massmarketed tax avoidance scheme deductions was 'you gave me the money, why should I give it back?' The most vocal group were blue collar workers of the Kalgoorlie region. A campaign of resistance was established in the Goldfields - 'Say No to the ATO'. The Prime Minister addressed public meetings. ATO officers visited Kalgoorlie, the centre of the Goldfields region.

Public protest ultimately resulted in a Senate Inquiry into the mass-marketed tax avoidance schemes and the resultant ATO recovery action. A Senate Economics References Committee was established on 29 June 2000 with terms of reference to consider:

i. The adequacy of measures to promote investor understanding of the financial and taxation implications of tax effective schemes;

ii. The conduct of, and the adequacy of measures for controlling, tax effective scheme designers, promoters and financial advisers; and

iii. The ATO's approach towards and role in relation to mass marketed tax effective schemes. ${ }^{121}$

The committee reported that '[o]ne of the critical factors in the debate over MMS [mass-marketed tax avoidance schemes] is the apparent time delay between growth of the MMS market and the ATO decision to crackdown on the schemes.' ${ }^{122}$ One of the key issues taken into account by the Senate inquiry was ' $[\mathrm{t}] \mathrm{he}$ time delay between the growth of the [mass-marketed tax avoidance schemes] market and the ATO's decision to disallow deductions associated with mass marketed arrangements.'

123

In order to establish an understanding of motivational factors underpinning taxpayer response to the ATO recovery action, researchers at the CTSI conducted a national survey of Australian taxpayers involved in tax planning schemes. ${ }^{124}$ The survey was primarily focused on how respondents felt they had been treated by the ATO and was an evaluation of sentiment towards the ATO in applying Part IVA particularly as to retrospectivity.

\footnotetext{
119 Australians for Tax Justice Incorporated; Puzey v Commissioner of Taxation [2004].

120 Interview with a scheme participant (Karratha, 25 June 2006); Extracted from ASIC's database at AEST 10:53:03 on 17 July 2008.

121 Commonwealth of Australia, above n 58, v.

122 Ibid 4.3.

123 Ibid 1.

124 Tina Murphy, Mass Marketed tax schemes: Findings from a survey of investors 2003 available at < http://ctsi.anu.edu.au/UP.Murphy.taxschemes.html > at 10 May 2005.
} 
The scale of the quantitative study produced a large volume of data for analysis and two aspects were chosen for the research question to be examined by way of in-depth interview in a qualitative study. Firstly to understand why and how people protested against the ATO, and secondly to ascertain why some taxpayers invested in massmarketed tax avoidance schemes while others did not.

The further research in support of that quantitative survey was a qualitative study by Hobson $^{125}$ in which several participants of mass-marketed tax avoidance schemes participants were interviewed in depth. Given that many of the submissions to the Senate inquiry ${ }^{126}$ were from affected Kalgoorlie taxpayers the qualitative survey was conducted in that population of mass-marketed tax avoidance schemes participants.

Despite an attempt to understand the motivational issues for taxpayers joining the schemes, focus was on taxpayer response to the ATO recovery action. It was largely inconclusive as to establishing reasons for engaging in the schemes.

The author concluded that:

Finally, research can never truly uncover individuals' initial motivations for investing in schemes, as they no doubt have become clouded by subsequent events. Even though many interviewees admitted wondering if they had been foolish and inept in their actions, they were reluctant to take the blame for events, as: 'even if being inept isn't one's fault, it still is a less than admirable aspect of selves [sic], one that we might conceal rather than advertise' ${ }^{127}$

After much political pressure and public protests agreement with tax administrators was reached. Penalties and interest where remitted and taxpayers given time to repay the 'over-refunded' sums. ${ }^{128}$ Legislation was introduced to provide for prosecution of mass-marketed tax avoidance scheme promoters ${ }^{129}$ and tax avoidance activity lapsed.

It is noted that as of 2008, tax avoidance activity by way of mass-marketed tax avoidance schemes appears to have declined. This paper suggests that it may not be a period of inactivity but rather a point in the cycle wherein it is undetected by taxation administrators.

\footnotetext{
125 Kersty Hobson, 'Say No to the ATO': The Cultural Politics of Protest against the Australian Tax Office’ (Working Paper No 37, Centre for Tax System Integrity, 2002).

126 Commonwealth of Australia above n 58.

127 Hobson, above n 125, 14.

128 Australian Taxation Office, 'Most mass marketed scheme investors set to benefit from interest reduction' (media release 2001/58 23 ${ }^{\text {rd }}$ July 2001); Australian Taxation Office, 'Tax Office announces settlement offer for mass marketed scheme investors’ (media release 2002/07, 14 February 2002).

129 Division 290 of Schedule 1 to the Taxation Administration Act 1953 introduced in 2006.
} 


\section{Conclusion}

The history of tax avoidance schemes of the 1970s, 1980s and 1990s in Australia provides evidence of a cycle of actions and reactions by tax planners, tax administrators and taxpayers. Each cycle introduces further complexity to taxation legislation and the development of the subsequent schemes. Complexity is one of the many factors, identified by numerous researchers, which have influenced the development of tax avoidance schemes.

Along with increased complexity, 'bureaucratic inertia' of revenue authorities in responding to tax avoidance activity emboldens promoters and taxpayers to engage in such activities. It also creates increased angst among taxpayers to tax administrators' responses in combating the schemes thereby encouraging another cycle of scheme design and promotion. 


\section{Bibliography}

\section{Articles/Books/Reports}

Bernard, John, et al (eds), Macquarie Concise Dictionary, (4 ${ }^{\text {th }}$ ed, 2006).

Braithwaite, John, 'Through the Eyes of the Advisers: A Fresh Look at High Wealth Individuals' in Valerie Braithwaite (ed), Taxing Democracy: Understanding Tax Avoidance and Evasion (2003) 245.

Braithwaite, John, Markets in Vice; Markets in Virtue (2005).

Braithwaite, Valerie, 'Dancing with Tax Authorities: Motivational Postures and Noncompliant Actions in Valerie Braithwaite (ed), Taxing Democracy: Understanding Tax Avoidance and Evasion (2003) 17.

Braithwaite, Valerie, 'Tax System Integrity and Compliance: The Democratic Management of the Tax System' in Valerie Braithwaite (ed), Taxing Democracy: Understanding Tax Avoidance and Evasion (2003) 271.

Clyne, Peter, The New Techniques of Tax Avoidance (1979).

Delany, Tom, 'Part IVA and mass marketed schemes’, (2005) 8(4) The Tax Specialist.

Deutsch, Robert L, et al, Australian Tax Handbook 2000 (2000).

Evans, Christopher, 'The Battle Continues: Recent Australian Experience with Statutory Avoidance and Disclosure Rules' Judith Freedman (ed), Beyond Boundaries: Developing Approaches to Tax Avoidance and Tax Risk Management (2008) 37.

Freedman, Judith, 'Defining Taxpayer Responsibility: In support of a General AntiAvoidance Principle’ (2004) 4 British Tax Review 332.

Grabosky, Peter N, 'The Deputy Crown Solicitor and the bottom of the harbour scheme' in Peter N Grabosky (ed), Wayward governance: illegality and its control in the public sector (1989) 143.

Hobson, Kersty, 'Say No to the ATO': The Cultural Politics of Protest against the Australian Tax Office' (Working Paper No 37, Centre for Tax System Integrity, 2002).

Lampathakis, Paul, 'Justice Scandal:Brokers 'let off', The Sunday Times (Perth WA) 30 November 2008, 28.

Murphy, Kristina, 'The Role of Trust in Nurturing Compliance: A Study of Tax Scheme Investors' (Paper presented at the Current Issues in Regulation: Enforcement Compliance Conference, Melbourne 2-3 September 2002). 
Murphy, Kristina and Byng, Karen, ‘A User’s Guide to 'The Australian Tax System Survey of Tax Scheme Investors’ ’ (Working Paper No 39, Centre for Tax System Integrity, 2002).

Myers, Allan J, 'Tax Avoidance and the High Court since Sir Garfield Barwick' (Lecture delivered at the Melbourne Law School, University of Melbourne, 12 April 2005.

Organisation for Economic Co-operation and Development, 'International Tax Avoidance and Evasion’ Issues in International Taxation (1987, 1).

Potas, Ivan, 'Thinking about Tax Avoidance' (1993) 43 Australian Institute of Criminology: trends \& issues in crime and criminal justice, 2.

Seldon, Arthur, 'Avoison: The Moral Blurring of a Legal Distinction without an Economic Difference' in Arthur Seldon(ed), Tax Avoison (1979) 1.

Slemrod, Joel and Yitzhaki, Shlomo, 'Tax Avoidance, Evasion, and Administration' in Alan J Auerbach and Martin Feldstein (eds), Handbook of Public Economics (2002) 3, 1423.

Torgler, Benno, Tax Compliance and Tax Morale: A Theoretical and Empirical Analysis (2007).

Torgler, Benno and Schaltegger, Christopher A, 'Tax amnesties and political participation' in Benno Torgler (ed) Tax Compliance and Tax Morale: A Theoretical and Empirical Analysis (2007), 264.

Tutt, Nigel, The Tax Raiders: The Rossminister Affair (1985).

Tyler, Tom R, Why People Obey the Law (2006).

Waincymer, Jeffrey, 'The Australian Tax Avoidance Experience and Responses: A Critical Review' in Graeme S Cooper (ed) Tax Avoidance and the Rule of Law, (1997) 247.

Webley, Paul, 'Tax compliance by business' in Hans Sjögren and Göran Skogh (eds), NewPerspectives on Economic Crime (2004) 95.

Woellner, Robin, et al. 1997 Australian Taxation Law 7th ed. (1997) 1416.

\section{Case Law}

Commissioner of Taxation v La Rosa [2003] FCAFC 125.

Cooke \& Jamieson v Federal Commissioner of Taxation [2002] FCA 131575.

Curran v Federal Commissioner of Taxation (1974) 74 ATC 4296.

Ensign Tankers (Leasing) Ltd v Stokes [1992] 1 AC 655. 
Federal Commissioner of Taxation v Peabody (1994) 28 ATR 344.

Federal Commissioner of Taxation v Sleight [2004] FCAFC 94.

Federal Commissioner of Taxation v Spotless Services Ltd (1996) 34 ATR 183.

Howland-Rose and Ors v Federal Commissioner of Taxation [2002] FCA 246.

IR Commrs v Brebner (1967) 43 TC 718.

Jacques v Federal Commissioner of Taxation (1924) 34 CLR 328 at 358.

Krampel Newman Partners Pty Ltd v Federal Commissioner of Taxation [2003] FCA 123.

Meredith v Federal Commissioner of Taxation [2002] FCAFC 271.

Phillips v Federal Commissioner of Taxation (1978) ATR 783.

Puzey v Federal Commissioner of Taxation [2003] FCAFC 197.

Ryan v Federal Commissioner of Taxation [2004] ATC 2181.

Tupicoff v Commissioner of Taxation (1984) ATC 4851 and 15 ATR 1262.

Vabu Pty Ltd v Federal Commissioner of Taxation (1996) ATC 4898.

Vincent v Federal Commissioner of Taxation [2002] FCAFC 291.

\section{Legislation}

Acts Interpretation Acts (1901) (Cth).

Income Tax Assessment Act (1936) (Cth) Pt IVA.

New Business Tax System (Alienation of Personal Services Income) Act (2000) (Cth).

Taxation Administration Act (1953) (Cth).

\section{Treaties}




\section{Other Sources}

Australian Taxation Office, 'Tax Office education on income splitting' (Media Release, 22 May 1977).

Australian Taxation Office, 'Tax Office on target' (media release 97/50, 30 ${ }^{\text {th }}$ October 1997).

Australian Taxation Office, 'Most mass marketed scheme investors set to benefit from interest reduction’ (media release 2001/58 $23^{\text {rd }}$ July 2001).

Australian Taxation Office, 'Tax Office announces settlement offer for mass marketed scheme investors’ (media release 2002/07, 14 February 2002).

Australian Taxation Office, 'Practical guide to Part IVA' (media release 2005/70, 13 December 2005).

Australian Taxation Office, 'Test Case Litigation Program', $<$ http://www.ato.gov.au/taxprofessionals/content.asp?doc=/content/57395.htm $>$ at 12 July 2008.

Commonwealth of Australia, Report of Enquiry Concerning the Deputy Crown Solicitors Office, Perth Anthony F Smith (1983) 134.

Commonwealth of Australia and Victoria, Royal Commission on the Activities of the Federated Ship Painters and Dockers Union, Final Report (1984) vol 1, 91. This report became known as the 'Costigan Report'.

D'Ascenzo, Michael, 'In Defence of the Rule of Law' (Speech delivered at the Taxation Law Workshop, Aitken Hill, Victoria, 26 - 28 October 2001).

Murphy,Tina, Mass Marketed tax schemes: Findings from a survey of investors 2003 available at

< http://ctsi.anu.edu.au/UP.Murphy.taxschemes.html > at 10 May 2005.

North West Shelf LNG Pty Ltd, 'A Brief History of the North West Shelf', (Press Release, June 2003)

< http://www.australialng.com.au/downloads/NWSALNG_brochure.pdf> at 15 February 2006.

Prebble, Zoë and Prebble, John, 'The morality of Tax Avoidance: Why the Legal Difference Between Evasion and Avoidance is Insufficient to Ground a Moral Distinction'(paper presented at the Australasian Tax Teachers Association Annual Conference University of Tasmania, January 2007).

The West Australian Saturday August 231997. 